Fairy Godfather 


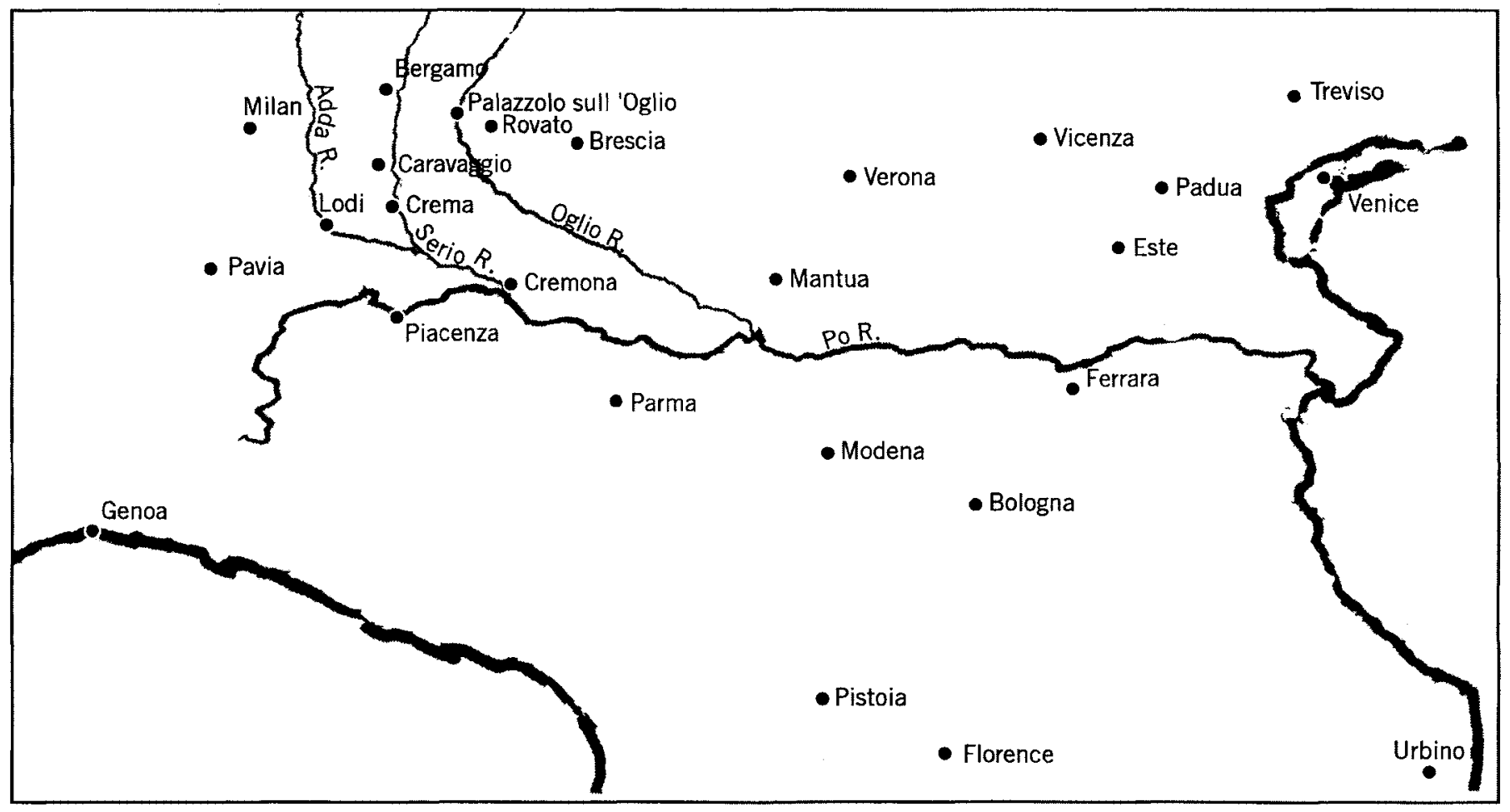




\section{Fairy Godfather}

Straparola, Venice, and the Fairy Tale Tradition

Ruth B. Bottigheimer

\section{$\overline{\text { PENN }}$}

UNIVERSITY OF PENNSYLVANIA PRESS

Philadclphia 
Copyright (C) 2002 University of Pennsylvania Press

All rights reserved

Printed in the United States of America on acid-free paper

\author{
IO $\quad 9 \begin{array}{lllllllll} & 9 & 7 & 6 & 5 & 4 & 3 & 2 & \text { I }\end{array}$ \\ Published by \\ University of Pennsylvania Press \\ Philadelphia, Pennsylvania I9104-40II \\ Library of Congress Cataloging-in-Publication Data
}

Bottigheimer, Ruth B.

Fairy godfather : Straparola, Venice, and the fairy tale tradition /

Ruth B. Bottigheimer.

p. $\mathrm{cm}$.

ISBN 0-8122-3680-7 (cloth : alk. paper)

Includes bibliographical references and index.

I. Straparola, Giovanni Francesco, ca. 1480-I557?-Piaccvoli notti.

2. Straparola, Giovanni Francesco, ca. I480-1557?-Homes and

haunts-Italy-Venice. 3. Fairy tales in literaturc. 4. Magic in literature.

5. Fairy tales - Italy-History and criticism. 6. Venice (Italy)-

Intellectual life - r6th century. I. Title

$\mathrm{PQ}_{4634 . S_{7}} \mathrm{P}_{523} \quad 2002$

$853^{\prime} .409-\mathrm{dc} 2 \mathrm{I}$

2002020425 